Andrew Nash

Andrew Nash is an associate professor in the Department of Political Studies, University of Cape Town. He taught previously at the universities of Stellenbosch and the Western Cape, and was editorial director of Monthly Review Press in New York. His book on The Dialectical Tradition in South Africa was published in June 2009.

Email: Andrew.Nash@uct.ac.za

\section{Zen Communist: Breyten Breytenbach's view from underground}

\title{
Zen Communist: Breyten Breytenbach's view from underground
}

In an interview after his release from prison, Breyten Breytenbach describes himself, at the time he became involved in underground politics, as a Zen Communist. He returns occasionally to this interaction of Marxist ideas of social revolution and Buddhist ideas of non-attachment, but never attempts to explain the resulting synthesis systematically. Indeed, for Breytenbach, being a Zen Communist is to resist systematic positions, to accept contradiction as a constant source of surprise and invention disruptive of all systematic thought. This paper examines how this interaction of Marxist and Buddhist ideas and practices has informed Breytenbach's politics in three contexts: his initial exploration of a radical philosophy of history in his poetry ("Bruin reisbrief", "Brown travel letter"); his role in the underground politics of Okhela in the 1970s; his reflections on politics and social change in his prison and prison-related writings. Key words: Zen communism, anti-apartheid movement, liberation, dialectic.

\section{"Not such a contradiction as all that"}

Around the time that Breyten Breytenbach became active in revolutionary politics, he also immersed himself in Zen Buddhism. Years later, imprisoned for terrorism in Pretoria, he recalled how, after making the vows of a bodhisattva in Paris, "a lock of hair was ceremoniously snipped off" and explained: "It's a cleansing process, a casting off of dead matter, a mental undressing, a way of taking leave of the world and becoming strong by making yourself vulnerable" (Confessions, 197$).{ }^{1}$

Later still, after his release from prison, Breytenbach reflected on this apparently paradoxical commitment:

To be a Zen Communist seems a contradiction, or at any rate peculiar - I believe I was the only clandestine activist in my dojo, I know I was the only Zen student in Okhela. But it's not such a contradiction as all that. The concreteness, shying away from abstractions, not manipulating facts or other people, forswearing personal ambition, attentiveness, awareness - all these are functional political precepts (Weschler 1998: 155).

Breytenbach describes himself as a Zen Communist only at that moment of his life, during the early 1970s, and he offers the description only in passing. But the figures 
of Buddha and Marx are often placed together in his writings. "Not only Marx," he wrote in 1969, "but already old Buddha and so many others before him in the bottomless mirror of time, have pointed out that people are bound to the results of their acts and omissions" (End Papers, 123). And in 1990: "Buddha helped me to understand Marx"; the Middle Way contains "the kernel of a dialectic encompassing continuous movement and engagement, for you can be neutral and unattached only if you are completely part of the process" (Memory of Birds, 36).

Even if it was only at that moment that Breytenbach actively sought to be a Zen communist, there is a sense in which the whole trajectory of his thought is informed by themes from Zen Buddhism and from Marxism, by the peculiar attraction and tension between them, and by the way in which that political identity had become imaginable to him once. Breytenbach's later critique of underground politics did not abandon the aspiration that led him into the underground.

On the one hand, he recollects the life of the underground activist as a "clean form of political activity, divested of the more mundane horse-trading and compromise of everyday politics," which allows a "certain purity of thinking", and "imposes a rigorous discipline" (Confessions, 81). On the other, he argues that this loss of self often enables the underground activist to be manipulated in undemocratic and sectarian ways. The idea that "we can make pure and honest militants" is mistaken. The "liberating concept," he holds, "is exactly to give over to the people the way a fish gives itself over to the sea; and also, despite, or because of the watery taste of failure in the mouth, to continue struggling" (Confessions, 86).

His critique of the underground is a quest for a different kind of underground, an Archimedean point more simply constituted, not that of clandestine manipulation but that of "becoming strong by making yourself vulnerable", finding a still point at the heart of the world's restless movement where its deepest aspirations can become lucid and clear. Rather than seeking to conduct politics in secret, this different kind of underground (middle world) accepts that social change is the result of processes so barely perceptible as themselves to be secrets, which guide us even when we do not entirely grasp their meaning.

For better or worse, being a Zen communist is to follow a way or tao, rather than to develop a theory or subscribe to a doctrine. It means that political ideas and arguments must be made real by being lived and by transforming the lives of those who uphold them, and that their meaning and significance depends on how they are lived.

It should not be held against Breytenbach that he is not a systematic political theorist. Such theorists all too often find systematic ways of justifying whatever political order is currently hegemonic. Breytenbach's thought moves in different, often idiosyncratic ways. But his political arguments have been developed, over many decades, in many genres, and in response to an extraordinary variety of pressures and circumstances, with a degree of coherence and consistency, originality and imagina- 
tive insight that give him a significant place in the history of South African political thought.

This article examines Breytenbach's political and intellectual trajectory from the perspective of Zen communism. It limits itself mainly to three contexts: his initial engagement in radical politics, around 1968; his role in the underground politics of Okhela, leading to his arrest and imprisonment in 1975; and his reflections on politics and history during and after his years in prison.

It is possible that Breytenbach's most important contributions to South African politics were made later, in his critique of the negotiated settlement and his seminal role in establishing a new politics of Afrikaans. Without grasping the complex development of his thought, however, his political responses to post-apartheid South Africa are all too easily misunderstood. His contemporary political pronouncements are often seen as a kind of provocation-a disruption of the rules of the political game. Provocation and disruption may be the result of not understanding the current game well enough, but also of understanding it all too well.

\section{Paris to Paestum}

In a smuggled letter to Marius Schoon, while both of them were prisoners in Pretoria, Breytenbach wrote that his political schooling - "if any, because I feel that it is only now that I am outgrowing my child's shoes [...] - was Paris", that is to say: Vietnam, May 1968, migrant workers, Tupamaros, Palestine, the revolutionary CP of Brazil. Much later, he was to describe Paris in 1968: "There were barricades in the street, daily we battled with riot police [...] debate flowed freely among all parts of society [...] But did we not then all believe that a new heaven and new earth were at hand?" (Welz 1977: 117-8).

Breytenbach's new political commitments were initially explored in his poetry. In the years after May 1968, the political character of his poetry shifted in several, related ways. Some poems take sides in the global struggles of the time, where previously he had focussed on South Africa. Others go further than before in their denunciation of oppression in general, and capitalism in particular. Among the poems written in these years, however, "Bruin reisbrief" ("Brown travel letter") from Oorblyfsels ("Leftovers", 1970) seems to me to stand out as capturing a new direction - bringing together past and present, local and global, into a reflection on the dialectical patterns of human history, which is at the same time a sharply focused comment on the struggle in South Africa. It also sets out his search for a deeper reality underlying political life, to be found in everyday sights and gestures - an underground created by poetic remembrance, not political strategy. Coetzee (1990: 45) describes this as "one of the most memorable documents of political protest in Afrikaans writing"; but it is as much elegy as protest. 
The poem begins with a journey through the south of Italy, which takes the poet to Paestum, near Naples, the site of the largest existing Greek temple, where the poem was written. It describes the efforts of poor farmers, 'southern people, brown, the brown of coloureds" - assisted by a "Central Authority" - to "bring this world to its own feet". From there the focus shifts to an imagined future in the driest, least hospitable parts of South Africa:

[...] And I saw the Karoo come into blossom

its hills anointed with thyme and rosemary

and villages like tendinous knots on the sinews of roads,

I saw water-furrows,

glistening, extended cobwebs across Namaqualand,

with settlements caught in them like flies,

fields of cotton in the valleys,

how even the Kalahari regained a green fertility -

a beautiful country open, open to all its people.

(Ysterkoei-blues, 281-2) $)^{2}$

From there, the poem returns to the Italian landscape, but this time to the ancient past still visible in the "virile race" which occupies it today. That ancient past and its ideals had to be "reduced to nothing, in order now, for the first time, to become its fruit." What remains of it in the present? "Nothing and everything," Breytenbach replies, evoking the lizard and the ant among the classical ruins where peacocks once strutted.

In its fourth and final movement, the poem is addressed to the Afrikaner, the product of a similar process of historical decomposition and regeneration. For they now seek to preserve themselves through apartheid, with a logic "like the Greeks who wanted to found a greater Greece here, and were wiped out by malaria". The poem closes in affectionate rebuke of "my brother, my barren, abandoned brother", and the wish that he will "blossom in people of brown". Afrikaners will become human in their brown descendants, gaining their humanity by abandoning their futile quest to preserve their supposed racial purity.

The poem draws on many of the existing themes of Breytenbach's work: death and decomposition as the source of life and regeneration, self-preservation as a barren death, the symbiosis of poor farmers with the land, the movement of imagination from present reality to past prefiguration, etc. But it makes use of these for a different purpose: that of constructing a dialectical philosophy of history with a political intent. The force of the poem's comment on apartheid arises not from the attitude of the poet, who speaks instead in tones of regret, even longing, but from its integral relation to the larger historical framework, which informs that comment.

The politics of the poem sits uneasily, however, with its philosophy of history. For the account of history presented here is that of an ineluctable process, indifferent to 
the ambitions of Greeks and Afrikaners alike. From the point of view, which it adopts, there need be no significant difference between Pericles and Dr Verwoerd. But the politics, which grows out of this philosophy of history, takes the form of a moral appeal to the Afrikaner "brother" - an appeal to transform the pattern, which the poem suggests, is as ineluctable as death and decay itself. Within the logic of the poem itself, it is not clear that this can be done. What can be done is not to change the course of history, but to make peace with it, to discover new aspects of the self by acting in harmony with the historical process, and to prevent the needless destruction which those with ambitions of immortality - Greek and Afrikaner alike - visit on themselves and others. But if this is the argument of the poem, it might as easily be the basis for an abandonment of politics.

In this ambiguity, the politics of the poem are strongly reminiscent of the leading Afrikaner revolutionary of the previous generation, Bram Fischer. Fischer's speech from the dock, at his trial only two years before Breytenbach's poem, set out a relatively determinist account of history clearly drawn from Soviet Marxism. But it gave two inflections of its own to that model of history. First, it suggested as the motive force for historical change ethical need, rather than material production:

Political changes [...] occur when the outmoded political form ceases to serve the needs of the people who live under the new circumstances brought about by the development of the new economic methods [...] Once the economic changes have occurred, the political changes are bound to follow [...] South Africa today is a clear example of a society in which the political forms do not serve the needs of most of the people (Fischer 1966: 14-5).

Second, Fischer's Marxism lacked any conception of conflict as a necessary part of the historical process. The overthrow of capitalism can take place peacefully or violently, he held, depending on "the circumstances at any given stage of history" (Fischer 1966: 13). In this context, the role of Marxism was not to clarify the lines of struggle, but to pre-empt it. For once political change has become inevitable, "the sole question is whether [...] the political changes will be affected by peaceful means or by violence and this depends in essence on the balance of forces at the time when the changes come and on the degree to which people understand the need for political change" (Fischer 1966: 23). Marxism is presented as the source of such understanding, that which enables contending groups "to get together and work out by discussion, and not by violence, a method whereby they can live together". Fischer's own sacrifice is made, then, to avoid a repetition of "that unnecessary and futile anguish" which was suffered during the South African War (Fischer 1966: 16).

The perspectives of Fischer and Breytenbach resemble each other in combining a philosophy of history which leaves little room for human agency with an ethical appeal to Afrikaners to conform to the course of history rather than resisting it. But 
Fischer's conception of the course that will be taken by history is relatively abstract. It is a linear and stagist conception in which the more advanced mode of production, and its corresponding form of state, displaces the outdated mode, and the Soviet state provides a model and end-point for the process.

In Breytenbach's poem, by contrast, the historical process is richly concrete, the outcome of the tenacity and passion of poor people - "the further south you go, the poorer the farmers become" - and the imaginative feat which makes green and fertile the Kalahari Desert itself. Rather than a relentless march through the stages of history, there is a dialectical sense of the tragic ambiguity of even the most singleminded projects, and a vivid sense of how coming to self-understanding is also a way of preparing for death. Fischer's account of history stands in the place of historical and philosophical enquiry, leaving him only to take his stand - and the heroism of the stand he takes cannot be doubted - for the cause which it vindicates. Breytenbach's account of history offers no pre-determined outcome. Every historical order contains the seeds of its own eventual demise, but this does not detract from the reality of its human achievements. The poem is a signpost, of startling clarity, of the road which was not to be taken by Breytenbach or by any of his contemporaries.

In a long poem, Kouevuur ("Cold Fire" / "Gangrene") written in the European winter of 1968-9, Breytenbach (Ysterkoei-blues, 205) revisited the grave where the poem, which had introduced his work, four or five years before described his own burial. When the grave was opened, a flower is discovered growing from the anus of the corpse, on which is transcribed Marx's account of the ceaseless self-criticism of proletarian revolution, taken from The Eighteenth Brumaire of Louis Napoleon (the poem quotes Marx's text in English). The quotation concludes with Marx's play on Hegel's aphorism from the Philosophy of Right: "hic Rhodus, hic salta". It is as if Breytenbach takes the work of revolutionary self-criticism to be completed. The time for his own leap has come. Soon after that, Breytenbach entered the very different world of underground activism, after being recruited in an ANC-aligned group in 1969. Thereafter his writings put forward a conception of history much closer to that of Fischer, and to the Soviet Marxism which had been so resoundingly rejected on the streets of Paris in May 1968.

\section{Okhela's contradictions}

For a South African in exile, being radicalized in the context of the Paris revolts of 1968 had considerable consequences. The politics of the South African liberation movement in exile were dominated by the South African Communist Party, which stood at the opposite end of the spectrum of left politics from Breytenbach and the revolutionaries of 1968 . 
Breytenbach has given several accounts of his entry into underground politics. In all of these accounts, a central role was played by Johnny Makatini, at that time the ANC's diplomatic representative in Algiers "from where he oversaw anti-apartheid activities in France" (Paradise, 122). This oversight was contested by the London office of the ANC which - according to Makatini and Breytenbach - was dominated by the SACP, which in turn had a very close relationship with the French Communist Party.

Atlas/Okhela focussed mainly on exposing European collaboration with apartheid, enforcing trade sanctions and the like. But Makatini believed that it could take on a larger political role within the liberation movement, as a counterweight to the influence of the SACP. He persuaded the president of the ANC, Oliver Tambo, to meet Breytenbach, and to give his sanction to the formation of Okhela. Where Atlas had been a small clandestine group engaged in anti-apartheid activities in France, Germany and the Netherlands, Okhela would be a pole of attraction for white leftists within South Africa - more specifically, for radical students, organisers in the emerging trade union movement, and dissident Afrikaner intellectuals. A major part of Breytenbach's clandestine mission to South Africa was to discuss the draft manifesto of Okhela with potential recruits.

Okhela was at cross-purposes with itself even before it came into existence. Makatini, Tambo and Breytenbach all had significantly different purposes in establishing it, and the area at which these intersected was obscure and changeable. Makatini was aligned with the "Africanists" within the ANC, who were resentful of the opening to all races of ANC membership (but not membership of its National Executive) at the Morogoro conference in 1969, and of the influence of the SACP, which they saw as the main force behind the adoption by the ANC of the explicitly anti-capitalist "strategy and tactics". He saw Okhela as a way of reducing the role of the SACP, and limiting the role of white leftists in the liberation movement to that of "support work in their own community" (Callinicos 1999: 134).

Although Tambo sought at that time to accommodate the Africanist group within the ANC, there is no evidence that he supported their cause. During the years in exile, Tambo's aim was to build as inclusive a movement as possible, and this was almost certainly his aim in initially giving his approval to the formation of Okhela. Finally, Breytenbach and his comrades sought to reduce the role of the SACP for very different reasons from Makatini. "Due to diverse leftist experiences during the sixties", he wrote (another shorthand for "Paris 1968"), "they felt a strong opposition to Stalinism" - that is, to the doctrinaire, bureaucratic and centralist line of the SACP. While they shared the SACP's commitment to creating a non-racial South Africa, they also felt that the SACP was "papering over the real problems of cultural awareness" and failing to learn the lessons of Black Consciousness (Confessions, 76). Callinicos (1999: 135) describes Atlas/Okhela as "a white, New Left alternative to the SACP, operating within the ambit of the ANC". The characteristic critique made by New Left Marxism 
of dogma and hierarchy had little in common with an Africanism concerned to promote a new dogma and new faces within the old - although racially restricted hierarchy of the liberation movement.

Breytenbach (Welz 1977: 117) emphasised - both in his smuggled correspondence with Marius Schoon and in his published account - that the critique of the SACP which motivated Okhela was "coming from the left". He told Schoon that his comrades were "Marxists and revolutionaries (and also not Trotskyists, although there were some Maoist tendencies to be detected)". Faced with Schoon's unflinching loyalty to the SACP, he still hazarded that "there are quite good South African communists outside the SACP" (Welz 1977: 126). In developing its own strategies, Okhela gave priority to support for the emerging trade union movement, which was dismissed by the exiled South African Congress of Trade Unions (SACTU) and was to be subjected to sustained hostility from the SACP once it came to adopt a political direction of its own.

But Breytenbach's self-definition as an anti-Stalinist "to the left of the SACP" was largely retrospective. During his years of clandestine activism, Breytenbach's political vocabulary was very similar to that of the Soviet Marxism, although juxtaposed with relatively undeveloped suggestions of a less centralised, more flexible approach. Breytenbach's ambivalence is captured in a 1972 discussion paper "contributing some elements towards a strategy for revolution in South Africa", which is in many ways a precursor to the Okhela manifesto. According to the paper, "our ultimate objective is a Socialist South Africa" in which a "new man" will come into being after "a taking of power by those who genuinely represent the workers and the peasants" (End Papers, 66). After setting out the complexities of the South African social order, the paper calls for a regrouping of "progressive elements, even those outside the liberation movement, into a revolutionary avante-garde, which will be closely, organically linked to the masses, work within the mass movements, learn from the people, help the mass organisations and the Liberation Movement in particular to evolve a clear strategy for revolution" (End Papers, 68).

This is the central ambivalence of the politics of Okhela: on the one hand, they acknowledge a well-defined "liberation movement" (the ANC and its allies); on the other, they assume it does not yet have a "clear strategy for revolution". A few paragraphs later, it recurs: "We must redefine, if necessary, the programme of the Liberation Movement" (End Papers, 69). But still there is no account of what its programme is, nor what problems require its redefinition, nor why this task should be assigned to Okhela. Breytenbach's own account of the nature of the South African struggle generally stays close to that of the ANC and SACP, asserting the theory of internal colonialism in more or less orthodox form, but adding that black consciousness is also a "necessary rehabilitatory answer to cultural colonialism" (End Papers, 67-8). 
The paper concludes: "The Liberation Movement must head the working alliance of Black Workers, of exponents of Black Consciousness, the Church leaders and the White Radicals, and reflect the struggle at any level at which it expresses itself" (End Papers, 70). This is to accept the leadership of a liberation movement and at the same time to dictate that it must ally itself with its rivals; to accept the idea of a "head" for that alliance, which provides its centralised planning and direction, and at the same time to juxtapose with it the very different idea that struggle should be "reflected at whatever level it expresses itself" - that is, without regard to the strategy of those at the "head" of that alliance.

In a paper presented in Groningen in the same year, Breytenbach (End Papers, 251) sets out the conception of history underlying this political perspective, arguing that "there is a dynamic evolution which contains jumps and advances in quality according to an ever-ascending spiral. Struggles reach certain levels, contradictions are seemingly resolved and new ones created. In this universe the tension between the two opposites of a contradiction is the force that allows societies to progress". It is in the name of progress - conceived as a continuous and linear process - that struggle, conflict and resistance are made necessary, in Breytenbach's argument. The Okhela manifesto, dated June 1975, brings together this triumphalist conception of dialectic ("the profound contradictions within South African society must explode [...] the Apartheid state must be destroyed"), with professions of loyalty to the ANC, and the idea of white radicals within Okhela playing a role "within the national Liberation Front being constituted" (Confessions, 385, 389).

But the politics of Okhela required not so much immersion into the historical reality of the South African struggle, but rather an unusually mediated and complicated relationship to that reality. At one and the same time, Okhela had to acknowledge the primacy of the ANC in the liberation movement, contest its alliance with the SACP, seek to lead a movement of students and workers within South Africa which was defined largely by its resistance to centralized leadership and to the politics of national liberation, and draw on white Afrikaner intellectuals to construct a more revolutionary path for the ANC.

Okhela was held together largely by a kind of voluntarism, exemplified by the decision to send its best-known and most conspicuous activist on that fateful secret mission to South Africa in 1975. Breytenbach (Confessions, 80) subsequently explained his acceptance of the task:

It was not my idea to go down there but I had to submit myself to the majority decision to do so. Stupidly vain, when told there were certain things which only I could do, it touched me, and I fell for it [...] I felt a moral commitment, a necessity to go. How could I pretend to lead an organisation of which some members would have to do dangerous things if I was not willing to do so myself? 


\section{Prison dialectics}

Before his illegal visit to South Africa, Breytenbach (Confessions, 139; see Coetzee, 1990: 44) spoke of compiling his final collection of poems, "because I have had my say". But imprisonment left him no other identity than that provided by words, and provoked an outpouring of them. From his release in 1982 until 1989, his prison writings were published in four volumes of poetry, a novel and a volume of literary reflection, as well as a prison memoir, a collection of political speeches and papers and a second novel that were the product of his prison years.

The starting point for Breytenbach's reflections in prison was a critique of the central conceptions of his years in Okhela: the idea of discipline, which defined the underground activist and decided his success or failure; the goal of power, which justified the sacrifices which the movement demanded; and the ostensible result of all of this, historical progress. Underground work forges "dedicated revolutionaries" conditioned into "unquestioned loyalty, discipline", among whom "relations are based on rock-bottom needs" (Confessions, 83). These relations are highly structured, "with information strictly channelled, with walls separating sector from sector, with a hierarchy that cannot be questioned". This "makes of underground work a very undemocratic process and it constitutes a structure which can be a very manoeuvrable vehicle for whoever happens to occupy the central nerve point." Breytenbach questions the "romantic view of underground work" and asks: "Has it ever been successful, apart from, in some instances, making it possible for the clandestine activist to come to power?" (Confessions, 85).

Discipline is justified by the needs of power. Questioning the cult of discipline therefore raises the question of whether power is itself the proper goal of the liberation struggle. For Breytenbach (Confessions, 309), it is not: "Power is a totalitarian concept. To realise that you are marginal is of itself a way of making distance your own, of becoming as permanent as an ice-block going downstream, of disregarding coercion. It is to come upon an interstice of freedom." Putting a new elite in power does not challenge the conventions of power itself: "Power structures are practically immutable and when broken down they're more likely than not to be replaced by others which are as exclusive and manipulative" (End Papers, 32). The quest for power in the name of liberation turns into its opposite: "All power needs interaction, relationships, intercourse [...] in order to exist. It is dialectical. You are not fighting ghosts, but your brothers [...] We are linked by our differences" (Memory of Snow, 128).

This leads to a more sceptical approach to the idea of progress. It is a fallacy, he argues (Confessions, 86), to postulate "that there is a measurable progress in the quality of human intercourse." In the life of the mind as in any other, growth and decay are inextricably linked: "There is no composition like decomposition: not just a rearranging or falling apart, but verily rotting to the bone to bring to light the essential structure" (Confessions, 151). He comes increasingly to view the linear idea of time as 
common ground for the apartheid regime and the liberation movement in South Africa. Marxist doctrines of historical determinism have mirrored Calvinist ideas of predestination. "The Party does not learn from the past, it becomes the recipient, the guardian of the accumulated weight of the past [...] time is an investment [...] Marx will be proved right [...] How is this any different from the Afrikaners' doctrine of predestination? [...] Are we doomed to become imitators of the people we are combatting?" Against Marxist or Calvinist ideas of redemption, he asserts the need to act in solidarity with the powerless without claiming the force of history on your side: "I need not believe or trust in the possibility of attaining the objective in order to keep moving. That would be falling into the progressist trap" (End Papers, 133; italics in the original).

The "progressist trap" occurs when one holds that progress is unmixed; that technological progress goes along with moral progress, and that we are justified in overlooking its human costs. When "political language" overlooks these costs, it makes itself liable to Breytenbach's charge (Memory of Birds, 72-3) that "it is never self-doubting, dark or broken". He describes his own task, in contrast with the tasks of the political, as "putting in motion the joyful despair of metamorphosis".

Having abandoned a linear view of historical progress, Breytenbach argues for a more conscious and ethical relationship to the passing of time, requiring individuals to decide on their role in validating what has gone before them. What is distinctive about Breytenbach's conception of time is the ethical relationship it establishes to the past. For the linear conception also claims to make ethical conduct possible in the present, but does so by treating the past as superseded, and emphasizing the causal relation of present conduct to the future. Once the linear conception is denied, however, there is no way of discharging your ethical responsibility by being on the side of the future rather than the past. The past and future are not necessarily in conflict. When they are, there is no easy resolution to be gained by siding with the future.

It is possible, for example, to acknowledge a background formed by racial and other forms of exclusion, and at the same time seek to develop a larger, non-racial community:

The dialectic between the "own" and the larger togetherness, between the specific and the general, is creative and progressive and transformative. It is also neverending, never resolved once and for all [...] What do you take with you of the old as you go over to the new? [...] I know only that I find myself exposed on that edge of becoming. Consciousness in movement is not a calm sea (Dog Heart, 186).

Instead, "you carry your history with you piece by piece, until it eventually falls to pieces" (Woordwerk, 202). ${ }^{3}$ The past has not been completed and left behind; nor does it provide an eternal and unchanging standard; but the past endures, and imposes on 
us the dialectical task of keeping alive its purposes precisely when they are least familiar in the light of the present. There is an obligation to resist the "Great Forgetting" (Die Groot Vergeet) of consumer culture (Woordwerk, 174).

In a recent work, Breytenbach (Veil, 72) puts this argument in terms that are less explicitly political and closer to the metaphysics of traditional Buddhism: "Identity is an ethical journey, a collage of scars and a work in progress spurting from the original void of 'self', the nothingness called 'life' you are left with when you crack the tiny banyan seed."

The linear view of historical progress implied by the "ever-ascending spiral" of Breytenbach's dialectic during his Okhela years could claim the merit of providing a common perspective to large numbers of people engaged in a common struggle. To some extent, very different struggles are welded together by a philosophy of history capable of interpreting them as parts of a single movement of progress. Within the ethical relationship to historical time proposed in his prison writings, it is difficult to see how any such common perspective could emerge. In the work which initiates Breytenbach's re-thinking of dialectic - at once an exposition of Zen Buddhism and an enquiry into the poet's craft - he asks (Boek, 170-4):

How do you gain access, in all clarity, to the whole within which opposites continue to exist without disrupting their symbiosis? [...] What Buddha proposed is no more than a method with which one can experiment; it is not a religion, or a serving of gods who can blindly be accepted once and for all. It must be grasped, and then constantly questioned [...] The key to Buddhist thought is independence and tolerance. ${ }^{4}$

Just as denying the linear conception of time establishes a new area of ethical responsibility, so in taking up this responsibility we locate ourselves more fully and firmly in history. "I' $m$ less of a threat to others when I'm at ease with my own unelucidated origins," Breytenbach (Dog Heart, 184) tells (a lightly fictionalised) Ampie Coetzee in a radio interview. He argues ("Andersheid," 43): "Ethics is important. If you 'choose' who you are, there is a deepened sense of finitude, of beginnings and endings and of purpose." ${ }^{5}$

This argument against the linear movement of history and for more consciously ethical responsibility towards that which is historically transient is a continuation of the Zen Buddhist theme of immersion into a process as a mode of political commitment and at the same time a re-working of that theme, which gives much greater emphasis to the conscious and critical detachment of the individual immersed in the process, and requires a more active historical sense. Rather than the metaphor of the fish in water - drawn perhaps from Mao's writings on people's war - that of the desert nomad, who must always move forward, is now more conspicuous (see Dog Heart, 165, 172). 
Thus, in a context in which history provides no certain direction, "the way forward is to keep moving" (Memory of Birds, 158). When all directions seem to be obstructed, "the point is to start anywhere. To continue then in the direction opened by that start. Whatever the way may be, wherever it may lead [...] The method I've decided on is to keep moving" (Memory of Snow, 215). The Middle Way of Buddhism "embodies the necessity of movement", not "circumventing and obscuring irreconcilable contradictions" but recognising that "it would be futile to sink into the static stance of waiting for the opposites to be resolved" (Memory of Birds, 10). The struggle against apartheid will not necessarily produce a better society, but at least the destruction of apartheid makes it possible for the other - "maybe better" - to take its place. For "there is no turning back; there is no self to turn back to" (Confessions, 239-40).

There is no self to turn back to, in the sense of a fixed and stable identity unchanged by the projects it undertakes. This is a constant theme in Breytenbach's writings (Boek, 88): "The self is a hearse. Death is the past, all the mutations of the 'self' which are now left to rot. You are always becoming, only a process." 6 You can turn back to the self, then, but it will not be the same self that you were when you began with the project from which you will later wish to turn back. "Memory is Kaggen, the trickster god. It says there is one certainty: nothing is what it seems. It says there is one finality: change" (Dog Heart, 188; italics in the original).

To think dialectically, in this context, is to think reflexively; it is to interpret the world in such a way as to make sense of the struggles of those seeking to change it and express your solidarity with them, but at the same time to remain aware of how you are changed by the process. For if the self is no more than the process of change which results from conscious identification with those struggles, then reflection on the self is necessarily a mode of thinking about how that solidarity is consistently to be maintained. Understood in this way, there is no need to interpret Breytenbach's account (Judas Eye, 133) of the task of the writer as inward-looking or apolitical:

Part of the civic poet's responsibility is to recognise the interstices, to be the thin wedge that could split the cracks, to seize the distaff elements and the moments of disequilibrium. He must be able to exploit the dynamic dialectical relationship of illusion, or appearance, with reality - knowing intimately the myriad ways in which the one becomes the other.

Increasingly, he views this relationship of illusion and reality as the product of a specific moment in capitalist development: "We are moving into exciting and frightening times where everything and its exact opposite seem to be true," he says in 1990 (Hart-lam, 34-5). "We live ever more by the reflection of reality, its staging, rather than by reality itself. We need to be told what is happening to us and then the telling becomes more real, is indeed the true happening." With the coming of liberation, independence and legitimate government, there is also "a television in every shack 
and pondok to wipe out memory". The image of the mirror recurs throughout Breytenbach's work, often to convey this effect: "Mirrors have a life of their own, and those who become trapped in them are doomed to continued existence" (Boklied, 77, 131). ${ }^{7}$

If the conception of dialectic developed in Breytenbach's prison years and after is taken as a whole, it can be seen as an attempt to formulate a discipline of mind embodying a conception of freedom as rational self-determination. "Power to the people," he wrote in a reflection on his talk to the UCT Summer School of 1973, "means that people are given the resources for self-knowledge, knowledge of the other (perhaps the same thing), and self-determination. To give the people back to themselves [...] We must still learn who we are; we must still become used to ourselves" (Seisoen, 134). ${ }^{8}$ After his release from prison, he told students at Stellenbosch ("Die game", 10): "My variant of power to the people is that everyone must think for himself, and the way I understand respect for my fellow-human is to allow each of them to think for themselves." ${ }^{\prime \prime}$ A decade or more later, Breytenbach's tone ("Andersheid",33) was more sober, but the argument was not fundamentally different: "In my experience, conscious awareness does not lead to certainty. I am not even so sure that it produces understanding. But a conscious life is all we have with which to undermine death."10

\section{Underground in the New South Africa?}

The most frequent criticism to Breytenbach's writings since the transition from apartheid began in 1990 is captured in his account of an encounter with Albie Sachs: "But aren't you ever happy? Now that we've won, can't you rejoice?" (Paradise, 160; italics in the original). The chance exuberance of a returned exile has become the refrain of newspaper columnists such as Max du Preez - rejoicing by now through gritted teeth.

After the release of Mandela and the unbanning of the ANC and other political organisations, Breytenbach returned to South Africa in August 1990, warning against the consequences of a victory over apartheid too easily won. In a series of interventions over the following years, he attacked the "false sense of consensus - actively connived at by the negotiators - namely that we know who we are and where we're heading" (Hart-lam, 35). This false consensus stands in the place of free and open debate about the direction which South African society is to take, and mobilization around different perspectives; instead, "one sees the participants in the various minutes and talks-about-talks-about-talks congregating in a kind of bureaucratic conspiracy of mediocre Boere-Stalinism" (Hart-lam, 40). The outcome of their negotiations, he warns (Hart-lam, 41), will reflect "the interests of two symbiotically dependent South African political formations which do not, cannot and are not mandated to represent the majority of us hoi-polloi". 
The threat of the negotiated settlement, according to Breytenbach's analysis, is threefold: conformity of mind; stagnation of identity; continued inequality. "South Africa's dominant culture is one of co-optation. There are still too many zones of silence, of accessory muteness, of reciprocal moral blackmailing living on hereditary guilt and the need to be humiliated," he told a Stellenbosch audience in 1990 (Memory of Birds, 26). South Africa is

caught between the plague and the cholera - between, on the one hand, Apartheid with its patriarchal and colonial tenets of Christian National Education, accompanying repression and the censoring of dissidence and deviation [...] and, on the other hand, a potential Stalinism, with its cultural commissars enforcing "people's culture" as populist idolatry through the appropriate "structures" $[\ldots]$ and where we shall again experience the marginalization of dissidents (Memory of Birds, 149).

In this context, "you need to be bewildered, again and again, until such time as you" re obliged to think for yourself. If you have to be stupid, at least be so with your own authentic foolishness" (Memory of Birds, 26).

In this context, reconciliation becomes "the reconciliation of two power machines - to broaden the base of pork barrel politics" (Hart-lam, 48). The inequalities of the past would be deracialized, but would continue and prompt new racial conflicts: "the Mandelas and the Mbekis and the Meyers [...] already live hand-in-pocket with the Oppenheimers and the Motlanas," while "the rough, white and black, unpoliticized lumpen proletariat" will "take each other on" (Memory of Birds, 145). The "political caste" will be guaranteed "untrammelled access to the state's feeding troughs while outside the slaughter continues" (Memory of Birds, 147).

Breytenbach seeks to disrupt the emerging consensus, but does not always make clear what is supposed to take its place. His most consistent theme is not the need for a national consensus with a different content, but rather for active exploration of differences, which does not necessarily have consensus as its aim: “I'd like to put in my plea for doubt and questioning, diversity, the maintenance of our 'Ho-Chi-Min trail' of underground tunnels of memory and resistance" (Memory of Birds, 149).

For all the power and eloquence of Breytenbach's interventions in these years, then, they remain strangely disconnected from the real conflicts of the time. There are many aspects of the transition to democracy which he foresaw more accurately than any of his contemporaries. But he could not make of that foresight the basis for any kind of resistance or opposition, nor has it been incorporated into any line of analysis - apart from that which has confined itself, self-defeatingly, to the issue of Afrikaans. For the central contradictions of the new South Africa lie not in the moral failings of capitalist or would-be capitalist politicians, but in the capitalist order itself. It is not that those who bring it into being wish to preserve and imitate the pretensions and habits of mind of the apartheid regime. They have no real alternative but to do so, for 
as long as the new South Africa derives its legitimacy from the democratic support of the oppressed majority, while carrying out the economic programme which serves the interests of the privileged minority.

In some measure, this failure can be seen as the product of Breytenbach's own lack of connection with the South African Left. After his release from prison, he quickly became an international celebrity, a prized item in the consumer culture against which he railed. For some years, he travelled widely in Europe and the United States (End Papers, 24-6). After 1990, he took on the same status in South Africa, moving "from airport to dinner table to lecture room" (Paradise, 217). In Zen terms, he acquired the "smell of enlightenment" (Kapleau 2000: 345), or had it bestowed upon him by the enlightenment industry in which he has been caught up, perhaps not entirely against his will.

But this failure cannot be attributed to Breytenbach alone. No one individual can be held responsible for the failure of a project which could only have been brought to any kind of completion within a vigorous and coherent culture of the left. Building such a culture is a collective task, which still lies ahead, beckoning us into the future.

\section{Notes}

1. When I cite Breytenbach's work I use a shortened title of the referenced work.

2. This and all subsequent translations are mine. The original reads: "[. . .] En ek het die Karroo in bloei sien kom, / sy koppies gesalf met tiemie en roosmaryn / en dorpies soos peesknobels aan die senings van paaie, / ek het waterslote gesien, / glinsterende uitgebreide spinnedrade oor Namakwaland / met die nedersettings soos vlieë daarin verstrik, / landerye katoen in die laagtes, / hoe selfs die Kalahari weer 'n groen vrugbaarheid kry - /'n mooi land óóp, óóp vir al sy mense [. . .]" (Ysterkoeiblues, 281-2).

3. "Mens dra die geskiedenis stuk-stuk met jou saam totdat dit naderhand heeltemal stukkend is" (Woordwerk, 202).

4. "Hoe verkry jy in alle helderheid toegang tot die geheel waarbinne teenoorgesteldes bly voortbestaan sonder dat dit die simbiose van stryk kan bring? [. . ] Wat die Boeddha voorhou is alleenlik 'n metode waarmee geëksperimenteer kan word; dis geen godsdiens of godediens wat eens en vir altyd blindweg aanvaar kan word nie - dit moet begryp en altyd weer bevraagteken word. [. . .] Die sleutel tot Boeddhistiese denke is selfstandigheid en verdraagsaamheid" (Boek, 170-4).

5. "Die etiek is belangrik. As jy 'kies' wie jy is, is daar 'n verdiepte sin van eindigheid, van beginne en eindes en van doel" ("Andersheid," 43).

6. "Die self is 'n lykswa. Die dood is die verlede, is al die mutasies van die 'self' soos hulle nou verrot. Jy is altyd wording. Slegs 'n proses" (Boek, 88).

7. "En nou het ons televisie in elke shack en pondok om die geheue uit te wis"; "Spieëls het 'n eie lewe en dit wat daarin verstrik raak, bly gedoem tot voortbestaan" (Boklied, 77, 131).

8. "Daardie 'power to the people' beteken vir my dat die volk die middels gegee word tot selfkennis, kennis van die ander (dis dalk dieselfde ding) en selfbeskikking. To give the people back to themselves. . . . Ons moet nog leer wat ons is; ons moet aan onsself gewoond raak" (Seisoen, 134).

9. "My variant van power to the people is dat elke ou vir himself moet dink, en my vergestalting van respek vir my medemens is dat elke ou juis vir himself kán dink" ("Die Game", 10).

10. "In my ervaring lei bewuswees nie na sekerheid nie. Ek is nie eens so seker dat dit mond op begrip nie! Maar 'n bewuste lewe is al waaroor ons beskik om die dood te ondermyn" ("Andersheid", 33). 


\section{Works cited}

Breytenbach, B. 1976. ' $n$ Seisoen in die paradys Johannesburg: Perskor. 1985. The True Confessions of an Albino Terrorist. London: Faber. 1986a. End Papers. London: Faber.

. 1986b. Die game is nog lank nie verby nie. Die Suid-Afrikaan, 6, 10-2.

1987. Boek (Deel Een). Johannesburg: Taurus.

1989a. Judas Eye and Self Portrait / Death Watch. London: Faber.

1989b. Memory of Snow and of Dust. London: Faber.

1991. Hart-lam. Johannesburg: Taurus.

1993. Return to Paradise. Cape Town: David Philip.

1996. The Memory of Birds in Times of Revolution. Cape Town: Human \& Rousseau.

1998a. Dog Heart. Cape Town: Human \& Rousseau.

1998b. Boklied. Cape Town: Human \& Rousseau.

1999a. Woordwerk. Cape Town, Human \& Rousseau.

1999b. Andersheid en Andersmaak, oftewel die Afrikaner as Afrikaan. Fragmente 4: 26-44.

2001. Ysterkoei-blues: Versamelde Gedigte 1964-1975. Cape Town: Human \& Rousseau.

2008. A Veil of Footsteps. Cape Town: Human \& Rousseau.

Callinicos, L. 1999. Oliver Tambo and the politics of race, class and ethnicity in the African National Congress. African Sociological Review, 3(1): 130-51.

Coetzee, A. 1990. Letterkunde en krisis. Johannesburg: Taurus.

Fischer, B. 1966. What I Did Was Right: Statement from the Dock in the Supreme Court, Pretoria, March 28, 1966. London: Mayibuye.

Kapleau, P. 2000. The Three Pillars of Zen. New York: Anchor Books.

Welz, M. (ed.) 1977. Breyten en die bewaarder Johannesburg: McGraw-Hill.

Weschler, L. 1998. Calamities of Exile: Three Non-fiction Novellas. Chicago: University of Chicago Press. 